UDC 821.113.4

\title{
Gayane Orlova
}

Moscow State Institute

of International Relations (University)

“\&” - “OR" - “IF" - “THEN" (“\&” - “ELLER" - “HVIS” - “SÅ")

\section{BY SOLVEJ BALLE: IDENTIFYING GENRE}

For citation: Orlova G. " $\&$ " - "Or" - "If" - "Then" (" $\&$ " - "Eller" - "Hvis" "Sa”) by Solvej Balle: Identifying genre. Scandinavian Philology, 2021, vol. 19, issue 1, pp. 164-175. https://doi.org/10.21638/11701/spbu21.2021.110

The aim of this article is to contribute to a deeper understanding of Danish minimalism by performing a genre analysis of Solvej Balle's four short prose books (brief fictional prose) - " $\&$ ", "Or", "If" and "Then" - written over a 23-year period, between 1990 and 2013. The four texts are connected by a commonality of motifs and thematic elements, identical form and linguistic structure and therefore they comprise a rather unusual tetralogy. Balle's texts are viewed in the context of the development of Danish literature of that period with an emphasis on minimalist aesthetics and their origins. Balle belongs to a generation of writers associated with the flourishing of minimalism in Danish literature at the end of the $20^{\text {th }}$ century. The characteristic features of her few works are their intellectual elitism and elaborate, sophisticated form. All of her works are experimental, but the four texts of the "tetralogy" are the quintessence of a genre experiment in search of a new minimal aesthetic. The article deals with the characteristic features of the formal organisation of the four books, including their linguistic structure that indicate the cross-genre nature of Balle's texts and allow to identify them as a hybrid of a pointillist novel and a prose poem.

Keywords: contemporary Danish literature, Solvej Balle, minimalism, pointillist novel, genre experiment, lyric prose, prose poem, fragmentation.

\section{INTRODUCTION: HISTORICAL AND LITERARY CONTEXT}

Solvej Balle belongs to a remarkable generation of modern Danish writers born in the 1960s who embarked on their careers in the late 1980s - early 1990s to challenge traditional patterns and experiment 
with literary genres and forms. This era can be described as the high day of minimalism in Danish prose.

Most of the writers from this generation graduated from the Danish Academy of Creative Writing (Forfatterskolen), founded in 1987 by Danish poet and linguist Per Aage Brandt and modernist poet and critic Poul Borum. Over the years, the Danish Academy of Creative Writing has produced such notable writers as Kristina Hesselholdt, Merete Pryds Helle, Helle Helle, Peter Adolphsen, as well as Solvej Balle who has consistently retained her commitment to experimental forms. Her writings also reveal a clear tendency to merge minimalism with lyrical prose.

Danish literature of the 1990s as such was defined by two opposite tendencies: while traditional Scandinavian narrative forms continued to develop, it was also a time of radical experimentation and attempts to modify and combine genre forms and find a new aesthetic [Pimonov, 2007, p.60]. It was the time when minimalism in Denmark emerged as a holistic phenomenon and "the discussion about minimalism as a literary movement occurred in Danish literary studies" [Bunch, 2003, p. 238].

The exact origins of Danish literary minimalism are controversial. V.Pimonov lists the concepts behind American Minimal Art from the late 1950s - early 1960s as well as the aesthetic of European short stories among its external sources [Pimonov, 2007, p. 60-61].

M. Ipsen, while acknowledging the role of Danish literary tradition in shaping Danish minimalism, suggests taking into consideration Norwegian minimalism as another source of influence:

One can trace the origins of Danish short prose to many places: the shortest and least regularly adventurous of H. C. Andersen's texts - "The Muse of the New Century" or "Picturebook Without Pictures" - Søren Kierkegaard's "Diapsalmata" from "Either/Or", Johannes V.Jensen's prose, as well as Peter Seeberg's, Raymond Carver's and Ernest Hemmingway's writings. You can also trace it to the laconic style of the Icelandic sagas, the fable, the romantic fragment, the American short story or the short-short story. But you can also trace it to Norway. Not many people have been aware of this perspective [Ipsen, 2008, p. 83].

Ipsen notes the impact of Norwegian "punktroman" or pointillist novel (very short texts united by formal criteria or a small text divided into many fragments - points) on the Danish minimalists 
of the 1990s. Among the Norwegian sources, he considers Paal-Helge Hagen's pointillist novel "Anna" (1968) to be particularly relevant. However, according to Lars Handesten, three very remarkable books were published in Denmark at the end of the 1960s: "Sometimes they love each other" (1969) by Charlotte Strandgaard, "Love from Trieste" (1969) and "Today it is Daisy" (1971) by Kirsten Thorup. As stated by Handesten, those texts were actually written as pointillist novels, which means that the pointillist novel appeared in Norway and Denmark simultaneously. Handesten links this disintegration of the traditional novel format of the late 1960s with the convergence between prose and lyrics [Handesten, 2013]. Taking cue from Kjærsti Skjeldal, Jakob Hansen also characterises the pointillist novel as a transition stage between the lyric and the epic, whose originality manifests itself as a result of the fusion, through the transformation of the traditional techniques [Hansen, 2000, p. 67].

Indeed, minimalism in general has deep roots in Danish literature as has the fusion of minimalism and lyric prose in particular. D. Koblenkova considers Paul La Cour's "Fragments from a Diary", published in 1948, as the beginning of Danish minimalism, noting, however, that the origins of this phenomenon should certainly be sought in the national literature of the $19^{\text {th }}$ century when the poetics of fragmentation were developed [Koblenkova, 2018, p.252-253]. Above all, in our opinion, the origin should be sought in the works of Hans Peter Jacobsen.

At the beginning of the 20th century, the technique of text fragmentation was developed by Johannes V. Jensen in his "Myths" - lyrical and philosophical sketches. This was an innovative genre at that time [Saltykov, 2009, p. 199] and, to a certain extent, it determined the evolutionary paradigm of Danish short prose. Speaking of the diversity of minimalist writing, Mads Bunch notes "small impressionistic or surrealistic texts characterised by repetitions, as we see, among others, in the Danish tradition" [Bunch, 2003, p. 241]. These texts, in which minimalism intersects with lyric prose, seem to be influenced by "impressionistic fragmentation", which, according to A. Korovin "implies first getting to know the details, whereupon a complete picture of the world appears" [Korovin, 2009, p. 91].

Although the 1990s literary revolution in Denmark should be considered within the framework of European culture in general, it is rooted in the national literary tradition as well. 


\section{SOLVEJ BALLE'S EXPERIMENTATION WITH NEW FORMS}

A trademark feature of the 1990s writers was experimentation with form and style in their early works, Solvej Balle being no exception. However, many "experimenters" later turned to traditional forms, and in this regard, Balle is an exception: whatever she writes is an experiment. The writer works with an extremely vast variety of literary forms, which, however, have several common features. Balle has a thorough theoretical education: in addition to a course at the Danish Academy of Creative Writing, she graduated from the University of Copenhagen with a degree in philosophy and literature. Her serious intellectual background manifests itself in her "not-for-everyone" works - exclusive, intellectual, conceptual, philosophical - all this despite the fact that Balle in her perception of reality is a lyricist, who clearly appreciates the poetry of the moment. Her literary works are always limited in volume and meticulously crafted in terms of language. The highly accurate use of the language reaches its peak in her short texts " $\&$ ", "Or", "If" and "Then" ("\&", "Eller", "Hvis", "Så”) created over a period of 23 years and forming an original tetralogy, interconnected through content and form.

In 1990, four years after her literary debut, Balle published the first book of these short texts - " $\&$ ". Eight years later, in 1998, a symmetrical answer entitled "Or" appeared. These very remarkable books, both early works by Balle, represent in fact a hybrid literary form while being true and most complete embodiments of the very principle of fragmentation in Danish literature. Gitte Mose considers Balle to be "in an aesthetic dialogue with the romantic fragments" as well as "the pointillist novel and the Bloomsbury group's stream-of-consciousness modernism" [Mose, 2000]. The texts also contain features conventionally associated with lyric prose.

In 2013, another 15 years later, two new and equally symmetrical books of short texts were published, entitled "If" and "Then" cross-genre books, in which the same principle of fragmentation is embodied, both in terms of structure and perception of reality. " $\&$ " and "Or" are both books of high artistic value and, in some ways, genuineness, whereas the two subsequent books written later in life can hardly be considered original and independent as for their content and form. Rather, they indicate a desire to renew the non-renewable, to replicate the unique. This is, to a large extent, a copy, an attempt to use the same 
form, the same formal devices, but for different purposes, in a bid to promote "the criticism of civilisation" [Daugaard, Vindum, 2003-2020].

The books are fully symmetrical, both in text layout and visual presentation. Each of the four texts is divided into five sections (or chapters). Each section consists of 12 or 24 separate passages - relatively independent pieces of text, divided in paragraphs, separated by spaces. On two separate occasions in the first book, one can speak of 11 and 10 paragraphs instead of 12, depending on the calculation method used. Each book is structured in the same way as for the number of paragraphs presented in the five sections: $12-12-12-24-$ 12. Thus, the penultimate - or the fourth - sections are the longest. Each paragraph has between one and ten lines, but, in general, the number of lines is between three and eight. Each book has 37 pages, including blank ones.

Since the paragraphs are separated from each other by regular spaces, the pages are narrow, and the arrangement of chapters and their numbers in all books is the same. As a result, a hint of graphic design can be recognised.

Each book is supplied with an epigraph to be decoded, the same principle applying to the message in the paragraphs and chapters for the true meaning of the entire book.

\section{LINGUISTIC FEATURES}

All four texts have a similar linguistic structure that even places them in a borderline category as poems in prose - "the prose which is very similar to poetry in what it says, but sharply opposite in the form in which the author's thoughts are expressed" [Orlitskii, 2002, p. 221] despite the deliberate surgical soullessness of an external observer with which the texts are constructed.

As stated by Mose, this poignant mixture of prose and poetry is influenced by Hagen's "Anna" - a book, which, according to professor Atle Kittang, offers the possibility of both metaphorical (i. e., poetic) and metonymic (i. e., prosaic) interpretation: "a metaphorical, meaning-expanding dimension - which we know from poetry and which liberates a vertical and centred co-poetry (meddigten) and a metonymic dimension which is peculiar to epic literature" [Mose, 2000]. Some paragraphs are visually divided into stanzas and look like a verse. 
A similar linguistic structure is preserved throughout all the four works. It includes, firstly, a high semantic density of the text. Balle herself calls these works "prose with holes" [Mose, 2000], meaning, apparently, a particular feature of minimalist prose, which represents "concentrated fragments with a high degree of meaningfulness (betydningsindhold)" [Fibiger, Lütken, 2005, p. 445] and offers a high potential for interpretation.

Secondly, there is an endless "stringing" of names for impersonal objects and persons, just as if the technique used by Joseph Brodsky in his poem "Great Elegy for John Donne" was smashed into fragments and served with an intermittent partition. The books contain a series of pictures and scenes, which, in turn, contain impressions and things.

The very titles of the first two books, " $\&$ " and "Or", indicate, according to Mose, the absence of a vertical connection between phenomena, manifesting their equality. Indeed, the text equates people and things, phenomena and objects. The text structure unites - or divides everything, but it does not change the essence of things: everything is all one and the same [Mose, 2000]. Expressed at the language level, this equation is extrapolated to the emerging picture of the world as a whole.

Thirdly, there is an abundance of pronouns (and even signs), especially third-person pronouns, that appear as a result of detachment and, in turn, create further detachment as well as designations of persons by their actions, functions or group affiliation: he, she, they, people, children, adults, "those who sleep on the plain", traders, " $\&$ and the other one", etc.

Fourthly, as mentioned above, the texts are rather discontinuous and contain numerous repetitions, which Bunch considers a persistent characteristic of minimalist literature [Bunch, 2003, p. 240]. The sentences are mostly simple and often incomplete, whereas compound sentences are of the shortest possible variety and, with very few exceptions, contain only one type of syntactic relation. Balle combines short and very short sentences, creating a feeling of discreteness within a continuous flow of ever-changing images. The paragraphs often will start and end without any connection to the previous or the next one, creating an atmosphere of anxiety, ambiguity or mystery. At the linguistic level, the continuity is maintained through repetitions of similar structures phrases, descriptions of phenomena, images - running through the entire text: rain, a leaf rustling underfoot, etc. Images and verbal units 
repeat themselves throughout several sections or even books. Events take place here and now (the present and the perfect are used), there is no historical perspective.

And finally, the fifth element of the linguistic structure is light, sound and colour as literary devices: sporadically scattered throughout the texts are occasional references to the sounds, the quality of light and the colour of objects. Crunching, the sound of falling, rustling, the light of lanterns, multicoloured rusty containers, and the grey-green world are not complete and full-fledged descriptions, but rather references and statements that surreptitiously affect the perception of the reader.

\section{CROSS-GENRE NATURE OF THE TEXTS}

Each section, or even each paragraph, is an independent and complete text that lacks any obvious connection with other paragraphs, let alone sections. However, all of them are subjected to a certain idea, which is reflected in the epigraph to the book. Some of the paragraphs could have been rearranged with seemingly no loss. This is a free-form composition. However, in these provided, specific sequences of new meanings are being created by capturing the discontinuous stream of consciousness.

The texts as a whole are characterised by their cinematic qualities and quasi-documentary technique for reflecting objects and phenomena: on the one hand, they contain clear visual images without commentary and explicit assessment, on the other hand, there are no obvious connections between the sequences, instead we see a rapid shifting of "frames", a rough linking of fragments.

Semantic gaps, sudden shifts, broken syntax, spontaneously appearing verbal leitmotifs, unexpected accentuation and quick switches all impact the reader's perception and determine semantic accents, just as it happens in a poetic text that is defined by an intense "interaction with the lexical environment" [Bobylev, 2015], or even results in a density of interaction, based on the concept of "tightness and unity of poetic line" introduced by Iu. Tynianov [Tynianov, 1924]. "The removal of objects from the automatism of perception" [Shklovskii, 1921, p. 13-14] is also accomplished through a deliberately detached impersonal style.

Balle is a poet of mood. The atmosphere is conjured, among others, by exploiting cross-cutting repetitive motifs associated with natural 
environments (rain, river, rustling underfoot, seagulls) or the movement of living objects (people performing simple actions), as well as by detached and seemingly irrelevant comments (Det er lige meget 'It does not matter' [Balle, 1990, p. 15]), or by equalising enumerations, which at the same time with extreme spareness outline a visual picture and minimise the nuances of the existence. Even eroticism in the text is neutered. Gaps are yet another device used to create a feeling of ambiguity and vagueness, as well as that of anxiety. Thus, in the first section of the first book after describing the stalls along the embankment, two paragraphs appear out of nowhere in which the motive of death clearly arises: either a murder is taking place (Kroppen folder sig som trappen 'The body folds like the stairs'), or someone becomes a witness of the murder (Han har ligget loenge 'He has been down for a long time'). However, it is neither clear whether the "he" is alive (Han bevoeger munden som i et smil "His mouth moves like he is smiling'), nor whether the " $\mathrm{I}$ " is the murderer (Jeg tørrer kniven af $i$ min kjole 'I wipe the knife on my dress'). Nor is it clear what is happening at this moment and if something is happening at all [Balle, 1990, p. 11].

The episode ends with a dispassionate flight of wet newspapers, packages and soggy cardboard (Våde aviser, poser og opløst karton), which through a simple enumeration are equated with human lives and feelings. Subsequently, in the third section, we already see a couple " $\&$ " and "the other one", then, in section four, the "I" and the "you" meet on "neutral ground", then we see a "we" as an intermittent erotic motive that culminates in a farewell also on "neutral ground". In the fifth section, the motive of death reappears: targets (sigtemoerker) are drawn on the clothes of the faceless characters, and it is unclear whether this is a game or a verdict.

All of this alternates with aloof enumerations of objects, movements and actions of other people, as depersonalised as " $\&$ " and "the other one" and even "I" and "you", with no characteristics or qualities of a living soul. This is the poetry of a dead world filled with shadows.

The rather intense experience of the first two books is somewhat weakened in the latter two, "If" and "Then". Firstly, the paragraphs are less variable in size, which forms a sense of monotony and predictability. Secondly, basically the same patterns are used as in the first two books. Thirdly, a certain historical past arises, which means a latent strengthening of narrative. 
Finally, subtle expressions of social criticism (bureaucrats - a negatively loaded word, journalists to beware of, as well as the opposition of natural and social phenomena appear in the books) have a jarring effect on the poetic beauty of the texts. Nevertheless, in a philosophical sense, they follow up on the line of " $\&$ " and "Or": everything passes and nothing stays, everything moves and changes (Vi lever af forskelle 'We live by differences' [Balle, 2013, p.22], Vi befinder os i et skiftende landskab 'We are in a shifting landscape' [Balle, 2013, p. 31]). The differences are balanced by the perpetual motion of life, symbolised by the river.

All four books are a free-form composition, a kaleidoscope of emotionally loaded images, fragmentary impressions, "fragments of text and life" [Pedersen, 2012], peculiar to literary minimalism as a whole.

Balle's books resemble a broken mirror whose fragments are glued to a sheet of paper with certain intervals. Different facets of a single reality are reflected in the shards, someone holds the "shard mirror" and verbalises the reflections, yet in the wrong order, so that the old connections erode away and new and unexpected ones arise because of the shifts due to wrong combinations of these "voiced" fragments.

\section{CONCLUSION}

As the present study indicates, Balle's four books should be considered as a borderline phenomenon between prose and poetry, graphically presented as prose, although visually organised. A high emotional tension is created with extreme spareness in a pseudo-impassive atmosphere. The emphasis on the subjective experience is carried out through deliberate objectification, whereas the atmosphere is formed through images piercingly naked and devoid of all that is superfluous. The reader can stick to separate passages and paragraphs or rely on the primacy of the whole, which does seem logical. A weak and disintegrating narrative is also characteristic for the texts, as well as a focused attention on the linguistic features, the syntax in particular. That said and bearing in mind the author's own definition of the writings as "prose with gaps", it can be concluded that the texts in question are cross-genre texts, a hybrid of the pointillist novel and the prose poem, transformed within the new aesthetics. 


\section{REFERENCES}

Balle S. \&. København: Forlaget Basilisk, 1990. 37 s.

Balle S. Hvis. København: Pelagraf, 2013. 37 s.

Bobylev B. Iu. N. Tynianov as an Innovative Philologist. 2015. Available at: https:// proza.ru/2015/05/26/840 (accessed: 02.12.2020). (In Russian)

Bunch M. Minimalismen i dansk 1990'er-litteratur: gennembrud og forudsætninger. Danske Studier, 98. København: C. A. Reitzels Forlag, 2003. S.236264.

Daugaard S. Solvej Balle. Forfatterweb. Opdateret af cand.mag. Vindum A., April 2020. Available at: https://forfatterweb.dk/oversigtzballe00/hvis-sa (accessed: 30.11.2020).

Fibiger J., Lütken G. Punktromaner og prosaeksperimenter: Christina Hesselholdt og Merete Pryds Helle. Litteraturens veje. Aarhus: Systime A/S; Gads Forlag, 2005. $540 \mathrm{~s}$.

Handesten L. Punktromaner og babysjæle - Charlotte Strandgaard og Kirsten Thorup. Dansk litteraturs historie på lex.dk. Published 03.01.2012. Available at: https://dansklitteraturshistorie.lex.dk/Punktromaner_og_babysjæle_-_ Charlotte_Strandgaard_og_Kirsten_Thorup (accessed: 20.11.2019).

Hansen J. Littercere verdensbilleder: menneske og natur hos Solvej Balle, Merete Pryds Helle og Niels Lyngsø. København: Museum Tusculanums Forlag, 2000. 111 s. Available at: https://library.oapen.org/bitstream/handle/20.500.12657/34936/342362.pdf?sequence $=1$ \&isAllowed $=y \quad$ (accessed: 30.11.2020).

Ipsen M. Norske inspirationer i dansk kortprosa. Passage, årg. 23, nr. 59. Aarhus: Aarhus Universitetsforlag, 2008. S. 83-98. Available at: https://tidsskrift.dk/ passage/article/view/4094 (accessed: 30.11.2020).

Koblenkova D. V. Features of Danish Literary Minimalism. History of Foreign Literature in Two Parts. Part 2. Sharypina T. A., Koblenkova D. V., Novikova V. G. Moscow: Iurait Publ., 2018. P. 251-262. (In Russian)

Korovin A.V. Specific of psychological analysis in Herman Bang's short stories. Scandinavian Philology. Issue 10. 2009. P. 82-92. (In Russian)

Mose G. Punkterede og fragmenterede tekster - og en mellemrumslæsning. Vinduet. Oslo: Gyldendal Norsk Forlag. Published 08.05.2000. Available at: http:// arkiv.vinduet.no/tekst.asp?id=141 note15fra (accessed: 30.11 .2020 ).

Orlitskii, Iu.B. Poetry and Prose in Russian Literature. Moscow: RGGU Publ., 2002. 685 p. (In Russian)

Pedersen K. Changing Landscape. The history of Nordic Women's literature. Published 05.02.2012. Available at: https://nordicwomensliterature. net/2012/02/05/changing-landscape/ (accessed: 30.11.2020).

Pimonov V. The Variety of Rounded Forms. The Minimalist Aesthetic and the Contemporary Danish Literature. Voprosy literatury, Issue 2. 2007. P.60-71. (In Russian) 
Saltykov A. A. "Myths" of Johannes V. Jensen - a New Novella Genre in the Danish Literature? Scandinavian Philology, Issue 10. 2009. P. 197-203. (In Russian)

Shklovskii V. B. The Theory of Prose. Moscow: Federatsiia Publ., 1929. 266 p. (In Russian)

Skjeldal K. Det voksne barn må have et navn - punktroman er godt og misvisende. Den blå port, 36, 1996. S. 7-23.

Tynianov Iu. N. The Problem of Poetic Language. Leningrad: Academia Publ., 1924. 139 p. (In Russian)

\section{Гаянэ Орлова}

Московский государственный институт

международньх отношений (университет)

Министерства иностранных дел РФ

\section{ЖАНРОВАЯ ПРИРОДА «ТЕТРАЛОГИИ" СОЛЬВАЙ БАЛЛЕ «\&» — «ИЛИ» — «ЕСЛИ» — «ТО»}

Для цитирования: Orlova G. "\&” - "Or" - "If” - "then" ("\&" - "Eller" "HVIS” - "SÅ”) by Solvej Balle: Identifying genre // Скандинавская филология. 2021. Т. 19. Вып. 1. С. 164-175.

https://doi.org/10.21638/11701/spbu21.2021.110

Статья посвящена определению жанровой природы коротких текстов датского писателя Сольвай Балле - «\&», «Или», «Если», «То», - созданных в период с 1990 по 2013 г. и, в силу общности формальных и содержательных признаков - мотивов, тематических элементов, языковой структуры, - составивших своеобразную тетралогию. Творчество Балле рассматривается в контексте развития датской литературы соответствующего периода с акцентом на минималистической эстетике и ее истоках. Сольвай Балле - представитель поколения писателей, с которым связан расцвет минимализма в датской литературе конца $\mathrm{XX}$ в. Балле - автор немногих произведений, разнообразных по жанру и форме. Характерные устойчивые черты всех произведений писателя - интеллектуальная элитарность и отточенная, рафинированная форма. Все ее работы экспериментальны, однако квинтэссенцией жанрового эксперимента в рамках минималистской эстетики стали короткие тексты «тетралогии». В статье рассмотрены особенности формальной организации четырех текстов Балле, в том числе их языковой структуры, позволяющие говорить о пограничной жанровой природе произведений, а именно о контаминации жанровых признаков пунктромана («точечного романа») и поэмы в прозе.

Ключевые слова: современная датская литература, Сольвай Балле, минимализм, пунктроман, жанровый эксперимент, лирическая проза, стихотворение в прозе, фрагментарность.

\section{Gayane Orlova}

PhD in Philology, Associate Professor,

Moscow State Institute of International Relations (University),

76, pr. Vernadskogo, Moscow, 119454, Russian Federation

E-mail: gajane-orlova@yandex.ru 


\section{Орлова Гаянэ Корюновна}

кандидат филологических наук, доцент,

Московский государственный институт международных отношений (университет) Министерства иностранных дел РФ,

Российская Федерация, 119454, Москва, пр. Вернадского, 76

E-mail: gajane-orlova@yandex.ru

Received: February 26, 2021

Accepted: April 15, 2021 